pigments. The second component is produced in amount and variety dependent on the factorial influences and interactions. This interpretation is in good agreement with the views expressed above. The limited, common intermediate would be $\mathrm{C}_{6}(A)$ at some stage in its history; $\mathrm{C}_{6}(B) \mathrm{C}_{3}$ corresponds to the variable component in the hypothesis of Lawrence and Scott-Moncrieff.

Little can be advanced in favour of most of the special theories that have been proposed to account for anthocyanin formation in plants. There is, for example, a curiously persistent idea that anthocyanins result in Nature from the reduction of flavonols. But the physiological evidence shows that oxidation rather than reduction is requisite, and the fact of occurrence of analogous flavones and anthocyanins together in a plant has no unique applicability to the flavonol-reduction theory. We must anticipate it also on the basis of the parallel formationmechanisms mentioned above. Thus the $\mathrm{C}_{6}-\mathrm{C}_{3} \rightarrow \mathrm{C}_{6}$ hypothesis of partly independent routes to anthoxanthin and anthocyanin implies the probability of similar orientations of phenolic groups in the aromatic nuclei of the xanthic and cyanic pigments. Accordingly we might expect to find, as we do, pelargonin with apigenin; the flavonol-reduction theory, however, requires the anthoxanthin to be a derivative of kaempferol in this case.

Actually, the constitutions of congeneric anthocyanins and flavones do not often correspond closely, and the flavones (flavonols) cover a wider structural range than the anthocyanins. It is especially to be noted that correspondence of unusual structures in the two groups is not observed ; the joint appear- ance of cyanidin and quercetin derivatives is not surprising because these are the most widely distributed representatives of their types.

Hypotheses depending on oxidation of known flavan types such as the catechins (state of oxidation of tetrahydro-anthocyanins) are in better accord with the facts, although there is little positive evidence in favour of them. Tetramethylcatechin affords bromotetramethylcyanidin bromide on treatment with bromine in dioxan containing peroxide, but the conditions for the oxidation of catechin itself to cyanidin have not been ascertained. More significant perhaps is the recognition of the wide distribution of leucoanthocyanidins (probably possessing the state of oxidation of dihydro-anthocyanins) which are found in almost all kinds of plant material. Inevitably the transformation of these substances into colouring matters of flavylium type must occur in Nature occasionally, but it does not follow that this route represents the standard mechanism. Two dihydroanthocyanidins, namely, cyanomaclurin and peltogynol, have been isolated and characterised; these are stabilised by the possession of a glucose-like oxide ring, and the related anthocyanidins are not found in the form of naturally occurring anthocyanins. The true leuco-anthoryanidins usually afford cyanidin on hydrolysis and autoxidation.

It is too early to attribute a predominant role to the leuco-anthocyanidins, but it is already safe to assume that their modification represents an auxiliary pigmentation process. It is possibly operative in autumnal reddening and in the coloration following injuries or decortication of leaves.

\title{
The Fulmar Petrel
}

\section{By Seton Gordon}

\begin{abstract}
$\mathrm{T}$ HE spread southwards of the fulmar along the coasts of the British Isles during recent years is remarkable. The earliest known British colony of fulmar petrels was on St. Kilda. This, indeed, was the only known colony in the British Isles until the year 1878, when a dozen fulmars founded a colony on Foula, in Shetland. In the following year the colony had increased to 20 pairs (Zoologist, 1879, p. 380). From that time until the present day the fulmar has spread, and is still spreading, down the coasts of Britain, and is establishing new colonies yearly along the rock-bound coasts of Scotland, England and Ireland.
\end{abstract}

Whence has come this great stock of birds? It is generally supposed that they are descendants of the St. Kilda colony, which has overflowed east and south. Harvie-Brown's notes in his "Vertebrate Fauna of the North West Highlands and Skye", published in 1904, are therefore interesting. At that time the fulmar was only beginning to extend its range, but even then Harvie-Brown was inclined to question the generally accepted belief that St. Kilda was the birthplace of these new colonists.

He writes:

"While there may be reasonable and probably just cause for supposing that SOME AT LEAST 
of our new colonies are off-shoots from the St. Kilda group (it is even possible they may aLL be so) still the difficulty intrudes itself that the earliest new colony-that of Foula-is situated furthest away from St. Kilda. It may be argued that there is no reason for attempting to prove an advance-line, either from St. Kilda, or from Faroe, in the case of such a wanderer and skimmer of the ocean as the fulmar petrel indeed is. If we only look at this one species, very likely students of dispersal and migration and distribution may 'get no furderer', but there may be more behind

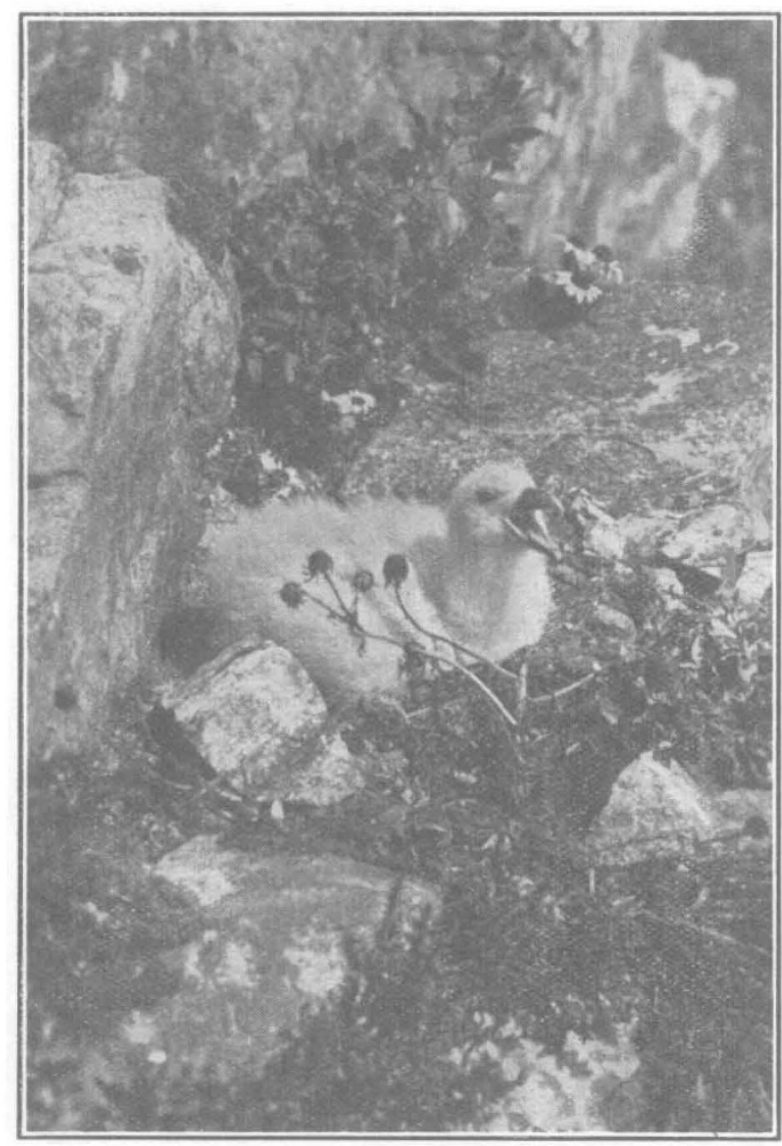

FIG. 1. A young fulmar petrel. (Photograph by Seton Gordon.)

THESE KNOWN FACTS. I think we have often in our series tried to define lines of advance and retreat and have perhaps a little forced our views with iteration. In this case I will not reiterate, but leave my readers to judge for themselves which may be the origin of our new fulmar colonies-Faroe, from the north, or St. Kilda, from the south."

St. Kilda is now uninhabited, but a number of years before the people left the island they had ceased, or almost ceased, to kill the young fulmars, and thus a large increase of the species was to be expected.
Martin, who visited St. Kilda in 1697, writes thus of the fulmar :

"The Inhabitants prefer this, whether Young or Old, to all other. The Old is of a delicate Taste, is a mixture of Fat and Lean, the Flesh White. no Blood to be found but in the Head and Neck. The Young is all Fat except the Bones, having no Blood but in the Head. When the Young Fulmar is ready to take Wing upon being approached, ejects a Quantity of pure Oil out of his Bill, and will be certain to hit any that attack him, in the Face, though Seven Paces distant. This he uses by way of Defence, but the Inhabitants take care to prevent it, by surprising the Fowl behind, having for this purpose a Wooden Dish fixed to the end of their Rods, which they hold before his Bill as he spouts out the Oil. They surprize him also from behind, by taking hold of his Bill, which they tie with a Thread, and upon their return home they untie it with a Dish under to receive the Oil. This Oil is sometimes of a Reddish, sometimes of a Yellow Colour, and the Inhabitants and other Islanders put a great Value upon it, and use it as a Catholicon for Diseases, especially for Pains in the Bones, Stitches, etc. Some in the adjacent Isles use it as a Purge, others as an Emetic : it is hot in Quality, and forces its passage through any Wooden Vessel.'

Martin calculated that sixteen thousand eggs of sea birds were given by the people of St. Kilda to his party during their three weeks' stay on the island. It is therefore evident that an incredible number of eggs were gathered annually, and when the young birds that were killed are also taken into consideration, it can be realised that the fulmars, and other St. Kilda birds, must now be increasing greatly and overflowing each season from that lonely island group.

In Seton's "St. Kilda" (published in 1878) occurs the following:

"Fulmar fowling begins on the 12th of August and lasts between two and three weeks. The fowlers are usually accompanied by a few of the younger women, some of whom can carry about two hundred pounds' weight of birds. The oil is extracted from the stomachs of both the young and the old birds, and enclosed in long distended bags, formed of the stomachs of old solan geese. The receptacle is held open by one man, while another, squeezing the body of the fulmar, forces the oil through its gaping bill. Each fulmar contains about half a pint of oil. The estimation in which the fulmar is held by the islanders may be gathered from the following words of a St. Kildan which are recorded in the pages of Macaulay, 'Can the world exhibit a more valuable commodity? The fulmar furnishes oil for the lamp, down for the bed, the most salubrious food, and the most efficacious ointment for healing wounds. Deprive us of the fulmar, and St. Kilda is no more'." 
That the fulmar is a comparatively recent arrival on the Faroes and is not everywhere welcome is shown by the following extract, also from "St. Kilda" :

"We must look also at the other side of the picture. What says the worthy Sysselmand, the King's Sheriff in Faroe, and deeply learned in fowl-lore? 'Thirty years ago, the fulmar knew his place : our fishers saw him out at sea 100 miles away, and only a stray bird now and then was driven hither by a heavy gale, but now he has set his ugly foot on my Holm of Myggenoes, and on the Goblin's Head of Sandö, and every year he spreads further and further, and breeds in more places. Nasty stinking beast! Why, even his egg keeps its stench for years : his flesh no man can eat, and yet this fellow thrusts his nose in among my gannets, and is slowly but surely driving them away'."

This account from Faroe is interesting, and it would appear that the fulmar was a resident on St. Kilda centuries before it colonised the Faroes, and the curious possibility arises that, even if the British coasts have been colonised by fulmars from Faroe and not from St. Kilda, they may be all the same the descendants of St. Kilda birds which overflowed at an earlier date to Faroe!

During the last thirty years, the fulmar petrel has steadily increased and extended its range. It nests in Orkney and Stroma, and among its Hebridean haunts are North Rona, Lewis, Pabbay, Bernera of Barra Head, Haskeir, the Flannan Isles, the Shiant Isles (where there is a considerable colony), Skye, Canna, the Treshnish Isles, Colonsay, and many other places. It nests freely along the mainland coast of Sutherland, and has spread to Ireland, where I saw a colony on Rathlin Island in 1935. It also nests on Tory Island in considerable numbers, and in other localities along the Irish coast. On the east coast of Scotland the fulmar nests from Duncansbay Head in Caithness, through Moray, Banff, Aberdeen and Kincardine, to St. Abb's Head. In Northumberland are several colonies, and it has now spread south to Flamborough Head and beyond it.* So far, the British Isles are the southerly limit of the fulmar's nesting range; it will be interesting to see whether colonies at some future date will be founded on the French coast on the Atlantic seaboard.

There are very few records of the fulmar feeding her young, and it is believed that the nestling must be fed chiefly during the hours of darkness. Mr. Armstrong, head lightkeeper of Rathlin, has given me an interesting account of the feeding of the

*The Northumberland fulmars had already arrived at the nesting rocks early in January of the present year. young fulmar in the late summer of 1935 . He writes :

"I have watched the fulmar returning to the young bird on the nest, and have noticed that she alighted about a yard from the nest and then seemed to disgorge food from the craw to the gullet. She then ambled up to the nest, opened her bill wide, and the young fulmar immediately put its beak down into the gullet of the old bird. It seemed to eat some sort of mashed substance, as it took its beak out after a few seconds and then worked its beak and swallowed. There was mashed material then adhering to the upper and lower

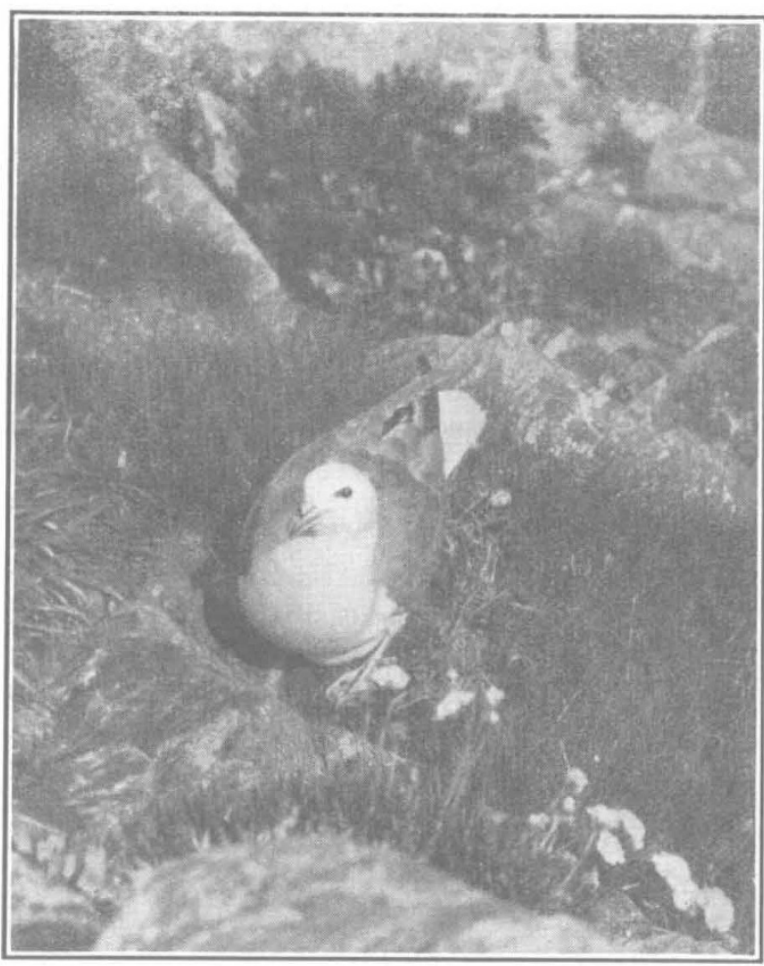

Fra. 2. Fulmar brooding on the nest ; note the conspicuous raised opening to the nostrils. (Photograph by Mrs. Seton Gordon.)

portion of the bill. I saw this scene enacted several times in the evening."

I believe it to be no exaggeration to say that each year a new fulmar colony is established somewhere on the coasts of Britain. It is, apparently, a peculiarity of this sea-bird of graceful, gliding flight that it colonises a sea cliff for a season, perhaps even for two or three seasons, before eggs are laid. There is a recently formed colony on the cliffs of northern Skye, near my home, and although at least thirty pairs of birds are seen soaring around their rock in April and May, very few eggs seem to be laid, and I doubt whether six birds in all have been reared during the last two summers. It is, of course, possible that gulls and grey crows steal the eggs; but I do not think this is the 
explanation, for this absence of eggs has been remarked upon at many newly-formed fulmar colonies. It seems more likely that these early colonists are immature birds.

The flight of the fulmar petrel is so beautiful and inspiring a thing that it is pleasant to watch this increase in the species, but it must be admitted that other seafowl do not like the fulmar as a nesting neighbour, perhaps because of the strong smell of the birds and of their young.
To see the fulmar in its greatest numbers one must journey to the Arctic. In Spitsbergen it nests inland, laying its egg on icy ledges amid the eternal snows three thousand feet and more above sealevel. There is something uncanny in the passing, always in silence, of fulmars through a desolate snowy valley by the pale light of the midnight sun. The fulmar nests in Franz Josef Land and Novaya Zemlya and in Iceland, and also in Arctic America. In winter it ranges south to lat. $43^{\circ} \mathrm{N}$.

\section{Physiological Bases of Nutrition}

$\mathrm{O}$ $\mathrm{NE}$ of the outstanding developments of recent years has been the steady progress throughout the world of the idea that the State is responsible for the material well-being of its individual members. A liberal food supply has always been regarded as one of the essentials for material wellbeing. Until recently, however, it was not realised how far the attainment by an individual of good physique, vigorous health and freedom from disease, could be brought about by attention throughout the whole period of his life to certain qualitative aspects of his habitual diet. It is now becoming plain to many of the Governments of States that they cannot afford to leave out of consideration the provision for their populations of food of the kind which tends to promote health.

$\mathrm{It}$ is obviously no easy task to change the feeding habits of millions of people. The kinds of food considered desirable must be available in sufficient quantity and at reasonable prices before any considerable changes can be effected. It has therefore become a matter of no little political importance to investigate the possibility of planning local, imperial and world agricultural and economic policies which would enable a sufficient supply of the more desirable kinds of food to be produced, transported and marketed, to meet the nutritional requirements of the populations of the world.

Such investigations have already been undertaken on behalf of certain Governments, and for some years the Health Organisation of the League of Nations has been interested in problems of this kind. The Assembly of the League invited the Council last September to appoint a committee, including agricultural, economic and health experts, to submit a report on the whole question to the next Assembly. The Health Committee appointed without delay a panel of twelve health experts to report on the fundamental problem which would determine the action to be taken afterwards by the agricultural and economic experts, namely, the definition of the nutritional needs of the human being in the course of his development from conception to adult age.

The Health Experts met in London last Novem. ber, under the chairmanship of Prof. E. Mellanby, and have now issued their report*. This report is divided into two parts, the first dealing with the energy, protein and fat requirements, and the second with the mineral and vitamin requirements. The energy requirements are based on the calcula. tion that an adult, male or female, not engaged in manual work, needs 2,400 calories a day. Those engaged in work should receive extra calories based on the nature of the work and the length of time they are engaged in such work. These extra requirements range from 50 calories an hour for light work up to 200 calories or more for very hard work. The calorie needs of children can be calcu. lated from a table of coefficients giving the basic requirements, to which are to be added extra calories to meet the needs for muscular activities; such activities may be considered to be equivalent to light work in the case of boys and girls aged seven to eleven years and of girls aged eleven to fifteen years, and to be equivalent to moderate work in boys aged eleven to fifteen years. For nursing women a basic allowance of 3,000 calories is suggested.

The protein allowance for all adults should be at least 1 gram for every kilogram of body-weight, and it is considered desirable that part of it should be of animal origin. During growth, pregnancy and lactation, some animal protein is considered necessary, and in the growing period it should form a large proportion of the total protein. It is recommended that pregnant and nursing women should receive 2 grams of protein per kilogram of body-weight. It is not thought possible to define

* League of Nations. Health Organisation. Report on the Physiological Bases of Nutrition by the Technical Committec appointed by

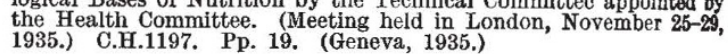

